\title{
GEOSPATIAL ANALYSIS OF LAND USE DYNAMICS USING HISTORICAL MAPS AND GIS TECHNIQUES. CASE STUDY OF RĂDĂUṬI, ROMANIA
}

DOI: http://dx.doi.org/10.18509/GBP.2018.63

UDC: 528.93:502.521(498)

\author{
Horodnic Vasilică-Dănuț \\ Graur Diana-Sofia \\ Afloari Mihai \\ Efros Vasile \\ "Ștefan cel Mare" University of Suceava, Romania
}

\begin{abstract}
Historical reconstruction of land-use and land cover dynamic often require comparing maps derived from different sources. Geographic information systems allow the extraction and quantitative analysis of information from historical maps. This study refers to the diachronic analysis of land use dynamics in the geographical area of Rădăuţi municipality, territorial-administrative unit located in the northeastern part of Suceava county, Romania. The analysis is based on the use of geospatial techniques in extracting information from historical maps, for emphasizing the land cover and land use dynamic from a spatial and temporal point of view. The cartographic and statistic analysis is based on the identification of a variety of land use categories: croplands, woodlands, water bodies, artificial surfaces, degraded and unproductive lands. Selection of historical maps at a large scale (Austrian cadastral maps, scale 1:2 880; the topographical plans, scale 1:5 000 and ortophotos, scale 1:5 000, updated with aerial images using Terra Incognita 2.41 software) allows a detalied analysis on the land use dynamics in the above-mentioned area. Complementary, temporal dyanamic of the land use categories is highlighted by the choice of some benchmark years, i.e. 1856, 1978 and 2015 corresponding to a different historical, geographic, social and economic context. The results obtained emphasize the territorial distribution and the dynamic of land use categories conditioned by natural and socio-economic driving factors which influenced with different frequency and intensity during of 159 years. The analysis revealed that the urban landscape has been very dynamic, displaying significant changes in most type of land use, most notably in the case of urban built-up, which emphasize substantial increases, from 134,93 hectares in 1856 to 773,42 hectares in 2015 . The analysis of land use dynamic is very useful for planners, because it can argue the best decisions regarding sustainable development of urban areas.
\end{abstract}

Keywords: land use, land cover, spatial and temporal dynamic, diachronic analysis, historical maps

\section{INTRODUCTION}

Land use and land cover dynamics implied automatically a change process resulting from human interactions in the environment. This fact has important implications for sustainable resource use and for environmental resource management. In the context of ever-increasing demands for space and resources for housing development, industrial practices, transportation network, tourism activities and agricultural production, the 
usefulness of land cover and land use analysis is critically, due to fact that it can provides the best solution for decision makers.

Land use is a concrete expression of human activity in space and time which accumulates a certain historical, economic, social and cultural potential and represent an intersection of natural conditions and human knowledge and techniques [1]. Each land use change reflects a change either in physic-geographic or socio-economic conditions of the studied landscape or both [2]. There are many definitions of land use and land cover. For this paper, land cover is defined as "the observed (bio) physical cover on the earth's surface" [3], while land use refers to the manner in which people use these biophysical assets [4]. Among the many concerns about global environmental change today, there is an increasing awareness of the importance of issues involved in land use and its changes over time, since land use is a key descriptor of human influence [5]. Land use and land cover change are among the most important alterations of the Earth's land surface [6]. Changes in land use and land cover are some of the far-reaching effects of human activities on modern landscapes. Among others, many of Europe's cultural landscapes have experienced a remarkable change since the early 19th century, particularly during the 20th century [7], [8], [9], [10], [11], [12], [13], [14]. Moreover, since the Second World War, land use and land cover and landscape transformation processes have accelerated [15], 16].

The way and the intensity of which a landscape is changed and transformed from one state to another is determined by various natural and anthropogenic processes. While the natural processes are mainly characterized by gradual changes in the landscape attributes, such as the loss of natural vegetation due to changes in the climate, the anthropogenic processes are usually very fast and cause abrupt changes in these attributes [17]. Current pattern and processes of land covers are part of the legacy from the past, and analyzing historical land use/cover change is essential to understand current human-environment dynamics and to predict the development of future land-use change [18], [19], [20].

In Romania, a theoretical framework regarding land use changes in the context of global environmental change was developed by Bălteanu [21], while Petrișor [22] realized an analysis of land cover and use changes in the context of urban growth in Romania. Other studies were mainly focused on the effect of land use changes on environment

In Suceava county, the mainly studies regarding land use and land cover focused on territorial units such as mountain valleys, river catchments, mountain massifs or administrative territorial-units.

The aim of the present paper is to analyze land use dynamics over almost two centuries (from 1856 to 2015) by a comparative examination of different historical cartographic supports and more recent maps, in order to obtain information about the changes that have occurred in the geographical area of Rădăuți Municipality, their connection to human activities and natural conditions, and the consequences for the evolution of built-up areas.

\section{Historical maps as a source of land use information}

Understanding long-term human-environment interactions is essential to understand changes in terrestrial ecosystems and it requires digital reconstruction of historical landcover changes [23], [24], [25]. Historical maps provide large potential for research into historical environmental change [26], [27], [28]. Historical maps, often embedded in GIS, have proven valuable for the analysis of land use land cover changes [29].

Historical maps can help to verify, concretize, or dismantle narratives about past environmental changes and political events [30], [31]. 
A special category of studies which analyses the changes in land use over time deals with information from historical sources such as old maps, cadastres, land registers, and other historical documents [32]. Historical cartographic materials are useful for retrospective analysis of land cover patterns and their change over time [25], [33]. Historical maps containing land-cover information with temporal layer, can serve as a basis for the reconstruction of past land use and land cover, especially when they are used in a geographic information system [34] Historical maps represent a unique information source of past landscapes and their combination with aerial photographs and satellite images creates a plastic image on landscape and its historical use [2].

The use of historical maps, which could be considered as a significant source of information about the evolution of land over time. A big advantage of this approach is that the maps already contain some information about the land cover or the way in which the land has been used. The accuracy of these maps and the number of land use categories which can be identified mostly depend on the map scale, the precision of the cartographic techniques used, and the topic of the map [32]. It is hypothesized that the use of multiple harmonized land cover land use statistics and maps would lead to improved estimates of change trends and better spatial allocation of historic change [35].

Besides, to make an intelligent choice for the future and to utilize land resources sustainably, we need to have a better understanding and quantification of historical and spatial-temporal patterns of land cover in the format of databases. These historical databases can also be utilized for various ecological, educational and management applications [18], [34], [36], [37].

\section{Study area}

The studied area is Rădăuți Municipality. It covers an area of 32,48 squares $\mathrm{km}$ and it is located in the northeastern part of Suceava county, the North-East Development Region of Romania, between following coordinates: $47^{\circ} 50^{\prime} 33^{\prime \prime}$ northern parallels, and $25^{\circ} 55^{\prime} 09^{\prime \prime}$ eastern meridians, as they are shown in figure 1.

The investigated area is overlapped on a relief dominated by Rădăuți Depression and it is situated at a mean altitude of 368 meters above sea level. The relief is dominated from a geological point of view by Miocene formations of Sarmatian age, more exactly, and by deposits of Quaternary age, which is the predominant surface deposits and by geological formations of Proterozoic age in the depth. From a climatic point of view, the study area experiences a temperate continental climate type with wet and cold influences for Romania territory generated by baltic nuances, with an annual average rainfall amounts to $634,8 \mathrm{~mm} /$ year, while the annual average temperatures reach $7,5^{\circ} \mathrm{C}$ [38]. The study area is situated in the middle basin of the Suceava river. Sucevița, Pozen, Saha, Temnic and Toplița streams are composing the hydrographic network of administrative area of Rădăuți Municipality. The typology of soils is strongly influenced by climate, hydrology, vegetation and relief, the dominant soils being represented by gleysols and fluvisols in this area.

The name of Rădăuți is derivated from "Radomirăuți", with a short name "Radovți" and the age of the settlement is attested by some archaeological discoveries made in the area of the Bogdana monastery dating from the Paleolitic age [39].

Known as rural settlement in the second half of the fourteenth century, the village appears for the first time mentioned on 18 November 1393, in a charter which Roman I Mușat, the prince of Moldavia (1391-1394), gave to some landowners a village on the Suceava river, whose boundary passes of the villages and Radomir's surroundings [39]. 

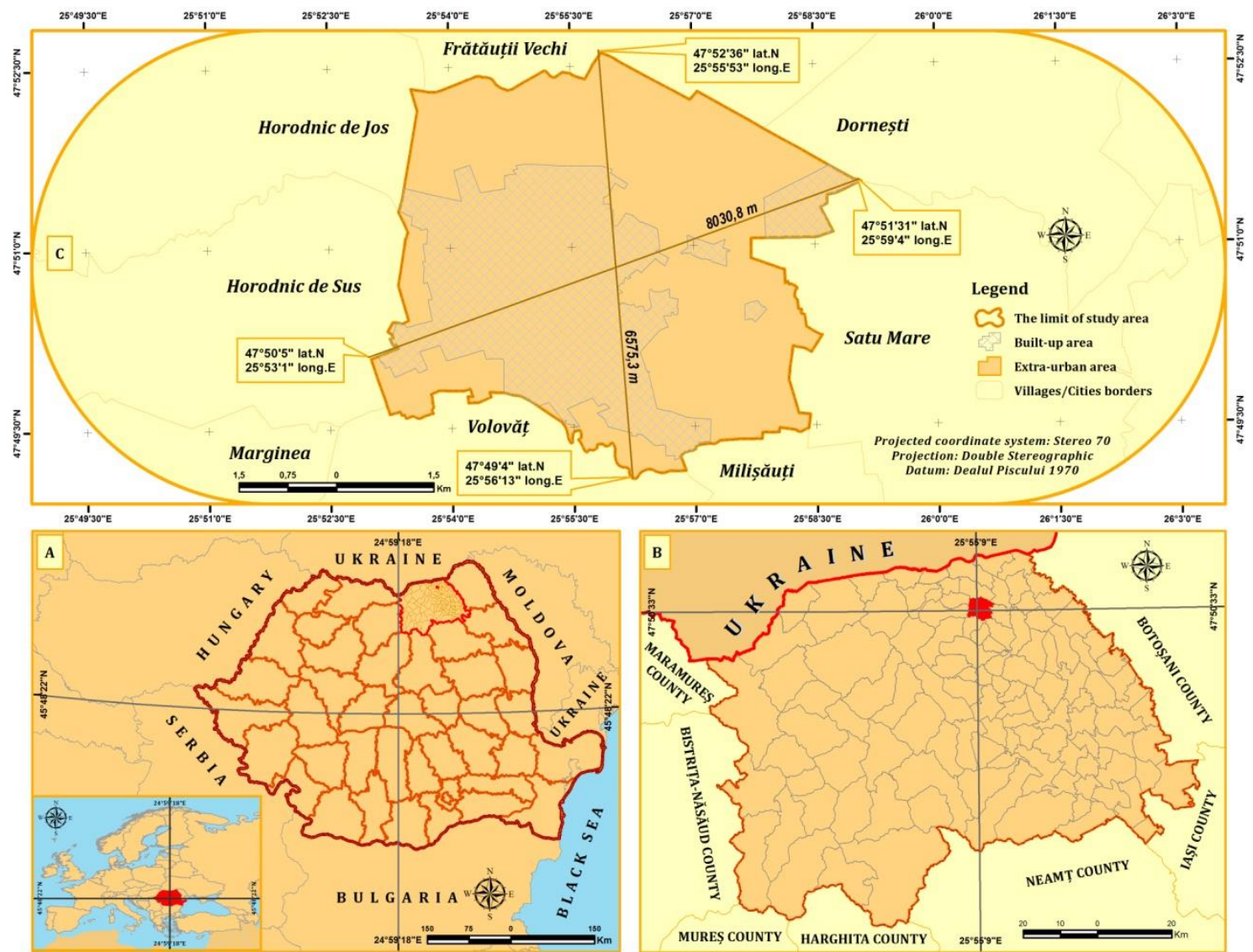

Figure 1. Location of the study area (A - in Romania; B - in Suceava county; C - details)

The earliest mention of the locality under the name of Rădăuţi dates from 6 July 1413, in a document which the prince of Moldavia, Alexandru cel Bun (1400-1432), passes in the possession of his mother-in-law, more villages and districts. During the government of Austro-Hungarian Empire (1775-1918), Rădăuți received in the 1819, the certificate of trade, in 1852 it was attested as urban settlement, in 1854 was called county seat and in 1995 was raised to the rank of municipality [40]. The number of population has varied over time, from 700 inhabitants in 1774 [39].to 22145 inhabitants in 2011 [41]. The mean density population is 682 inhabitants $/ \mathrm{km}^{2}$. The socio-economic structure of population is dominated by tertiary sector, despite of the fact that the dominant land is represented by agricultural land $(64,47 \%$ in 2015$)$.

\section{MATERIALS AND METHODS}

The methodological approach of this paper consists of three major steps. The first step consists in data collection (historical maps and ancillary data). Secondly, we performed the georeferencing and processing of the historic maps into a GIS environment. In this step, we applied a manual digitization of historical data and realized a thematic generalization.

The third step consists in a spatial and temporal reconstruction of historic land use land cover and in a statistical analysis of land use land cover categories dynamics (Figure 2). 


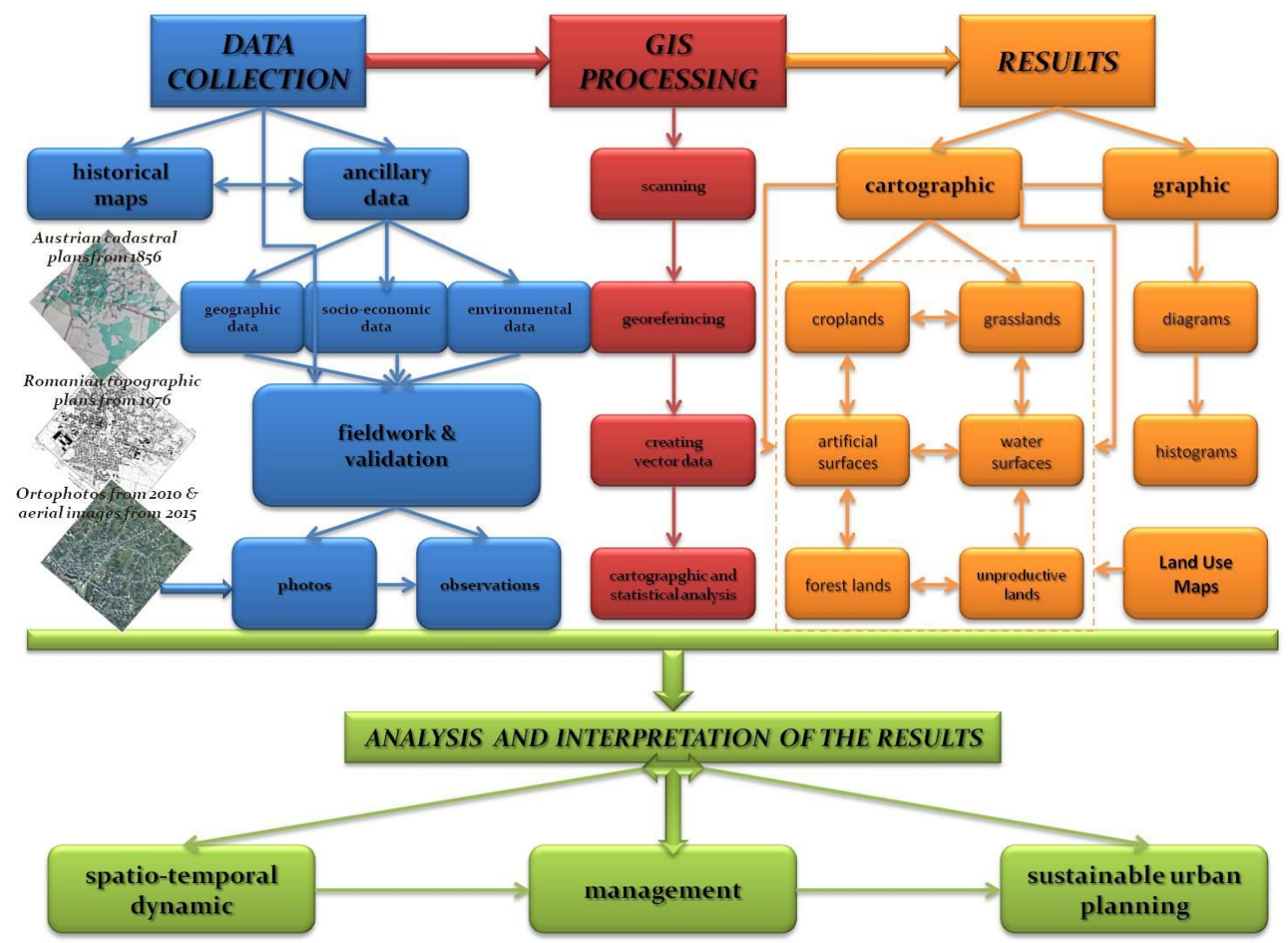

Figure 2. Flowchart of the methodological research steps.

\section{Data collection}

Historical documents contain qualitative or semi-quantitative information about past land use, which also usually include land cover data, but preparation of archival documents is very time-consuming. Historical maps and pictures offer visual and spatial quantitative land-cover information. The method does not only reconstruct the quantity of land cover land use in historical periods, but it also reproduces the spatial distribution. Reconstruction method based on multiple-source data and multidisciplinary research could build historical land cover from multiple perspectives, complement the missing data, verify reconstruction results and thus improve reconstruction accuracy [34].

For a long time, historical maps on paper were the sources of information mainly for the historians [42]. However, with the application of the GIS software and development of the digitization technology, historical maps can be used also at studying the development history of the landscapes [43], [44], 45].

To analyze the urban land use dynamics that have occurred at the Rădăuți municipality between the 19th century and the present day and perform a cartographical reconstruction of land cover, land use categories, we have used two historical maps: the 1856 Rădăuți cadastral plans and the 1978 Rădăuți topographical plans. The contemporary map used is an orthophoto from 2015, updated with other aerial images from 2015.

Since the beginning of nineteenth century in the Bukovina area, conditions were favorable to the development of a modern cartography, due to utilization of modern techniques for territorial and geographical surveying. The effectiveness of the cartographic sources used in the present study is related to their historical land use data content. The maps of 1856 and 1978 were realized based on geodetic surveys. 
The cadastral map of the Rădăuți area from the year 1856 meets of the 213 map sheet and is composed from 17 cadastral plans at 1:2880 scale, which were drawn during the period when the territory was controlled by Austro-Hungarian Empire. They were drawn in the period 1817-1856 from order of Franz I, for this reason this cadastre is called Franciscan cadastre. The map was of very high quality and is accurate in symbolism of land use features and toponomy. The real purpose for this fully territorial research regarding land fund was to establish the real size of taxes for the value of the land and these taxes must be stable for a long time, thus this type of cadastre is called the stable cadastre.

The historic topographic map of 1978 was produced by the Institute of Geodesy, Photogrammetry, Cartography and Territorial Organization to create a complete mapping of the Romanian territory. Geodetic surveying and topographic evaluation were highly accurately, thus land use categories were very easily identified. The scale of the sheet map is 1:5000 and the altitude was represented by contour lines having an equidistance of 2,5 m and by a high density of elevation points. The topographical map of Rădăuți area from 1978 is composed from 13 sheets. Each sheet has a form of trapeze with the size $44,76 \times 44,33 \mathrm{~cm}$. The quality of the survey allows an accurate geo-location and assessment of land use categories.

The recent cartographic support of the year 2015 were available in GeoTiff(.tif) format and were the product of the National Cadastre Real Estate Advertising Agency. Orthophotos mosaics at 1:5000 scale obtained from aerial photographs taken in the year 2015 updated with aerial images from 2015 downloaded with TerraIncognita software (version 2.41) were used to determine land use map for the year 2015. Each orthophoto is made of three RGB visible bands with an average pixel value of $0.5 \mathrm{~m}$. It is georeferenced in the Stereographic 70 projection. This type of data combines the image characteristics of a photograph with the geometric qualities of a map, i.e., the ground features are displayed in their true position, so it is possible to carry out direct measurement of distance, areas, angles and positions [46]

\section{Georeferencing and data processing}

The historical maps which were used in this study were available in the form of nongeoreferenced raster images (the case of maps from 1856 and 1978) and georeferenced raster images (in the case of contemporary maps from 2012 and 2015). In this way, the historical maps were scanned first and then imported and georeferenced into a GIS system.

To georeference historical maps (1856 and 1978) a sufficient number of control points on a georeferenced map was identified (from topographic maps of Topographic and Military Direction from 1986). This operation is known as "Image-to-Image" method. Several points were chosen as a control points and a third order polynomial transformation were used. After the historical maps were georeferenced, we realized a mosaic of sheets.

After the historical maps were scanned and georeferenced, they still do not contain any explicit information about the way land is used. Before using these maps in analyses of land use dynamics, the individual types of land use together with their boundaries have to be identified and saved into a vector file format.

This process is also known as "digitization" and is usually carried out using GIS software. Despite the fact that nowadays there are numerous techniques that enable automatic digitization [47], [48], the character of the historical maps (the ambiguity of land use type borders) prevented us from using any of them. Instead, the maps were digitized using a manual digitization technique, which is very slow but reliable and accurate [49]. 
Digitalization of the spatial data defining individual forms of land use was performed using the "on screen" method. It was conducted manually according to the analogue (visual) interpretation of maps and aerial orthophotos in the ArcGIS environment. Using this technique, the individual types of land use and their respective boundaries are manually identified. The manual digitization of the historical maps from the three time horizons (1856, 1978 and 2015) resulted in the identification of various number of land use types. The different number of land use types identified were the result of the varying details and scales of the maps.

\section{Thematic generalization and land use, land cover analysis}

The third step of methodological research is represented by the analysis of land use land cover dynamics during 159 years (1856-2015). Land use dynamic and geographical reconstruction of land use, land cover categories were carried out in three time steps: 1856, 1978 and 2015. The specific cartography for each period was examined with the aim to create different thematic maps and to make comparisons between 1856-2015.

Table 1. Classification scheme applied in the analysis of land use land cover dynamics

\begin{tabular}{|c|c|c|}
\hline Class name & Component class & Description \\
\hline Croplands & $\begin{array}{l}\text { arable lands } \\
\text { orchards }\end{array}$ & $\begin{array}{l}\text { includes all types of cultivated } \\
\text { area, i.e., arable lands, planted or } \\
\text { bare crop fields, permanent } \\
\text { crops like orchards }\end{array}$ \\
\hline Grasslands & $\begin{array}{l}\text { Pastures } \\
\text { Hay fields }\end{array}$ & $\begin{array}{l}\text { includes vegetation with } \\
\text { herbaceous species, low } \\
\text { occurrence of shrubs, high herbs } \\
\text { in the case of hay fields }\end{array}$ \\
\hline Woodlands & Vegetated stream beds & $\begin{array}{l}\text { includes densely vegetated } \\
\text { stream beds; plant communities } \\
\text { dominated by broadleaved tree } \\
\text { species such as willow, } \\
\text { everglade, poplar, wide-spread } \\
\text { along the streams }\end{array}$ \\
\hline Water bodies & $\begin{array}{c}\text { Lakes } \\
\text { Hydrographic network }\end{array}$ & $\begin{array}{l}\text { includes natural lakes, reed } \\
\text { water and local streams }\end{array}$ \\
\hline Unproductive lands & Pebbles & $\begin{array}{l}\text { includes temporarily flooded } \\
\text { stream beds with very sparse or } \\
\text { no vegetation, pebble and gravel } \\
\text { pits along the river valleys }\end{array}$ \\
\hline Artificial surfaces & $\begin{array}{l}\text { Built-up areas } \\
\text { Commercial units } \\
\text { Green areas } \\
\text { Cemeteries } \\
\text { Road network } \\
\text { Railway } \\
\text { Drainage channels }\end{array}$ & $\begin{array}{l}\text { includes highly developed } \\
\text { buildings, residential buildings, } \\
\text { commercial and industrial units, } \\
\text { urban utilities, leisure areas, } \\
\text { infrastructure to regulate water } \\
\text { flow and groundwater level }\end{array}$ \\
\hline
\end{tabular}

Each map reported different land use land cover categories and some categories did not appear in some of the maps. In order to carry out a direct comparison of land use maps, it was necessary to apply a thematic generalization [5], [25], [50], [51]. In this way, we created six classes of land use categories reported on the reference maps of 1978 and 2015 (croplands, grasslands, woodlands, water bodies, unproductive lands and artificial surfaces) and just five classes of land use categories reported on the reference map of 
1856. We adopted a similar legend with Corine Land Cover classification system, but in some cases with some particular names, adapted at local geographical conditions, resulting from a generalization and grouping of land use land cover categories. We use in this study a classification system distributed on two levels: level 1 or main class (croplands) and level 2 or component classes (arable lands, orchards $\div$ see Table 1 ). So, the finality of this operation consists in the creation of a database containing information about land use land cover categories for the studied area.

For each category of land use land cover, we calculated the total area expressed in hectares (ha) and the percentage of its variation over the time was calculated. The analysis was comprised of a comparison of the percentage of the individual land use categories in the total area of the studies area. Such type of diachronic analysis gave us information about total increase or decrease of the particular land use categories within the selected time periods represented by the temporal mapping. Geographical distribution of land use land cover categories for the years analyzed was performed by creation of thematic land use maps.

\section{RESULTS}

\section{Georeferencing and accuracy results}

All sheets maps from 1856 and 1978 were georeferenced with third order polynomial transformation. For each sheet map, were used at least four points of correspondence from topographical map or from orthophotos. The average RMS of each sheet map was around 0,5 and 1,5m for each sheet of 1856 map and 1978 map, respectively. The error associated to the transformation was calculated from the link tables by ArcMap 10.2.2. The RMS error is a good indicator of the georeferencing accuracy.

\section{Analysis of land use dynamics}

According to the system classification adopted, time series of land use land cover maps of three periods under study were developed and are presented in figure 3 (A, B and C). In the same figure, we are presented the evolution of the areas in hectares occupied by different land use land cover classes (Figure 3 - D). The analysis of the evolution of land use was made according to the land use categories identified during the three analyzed years. Alongside the diachronic spatial distribution of land use classes, the analysis was completed by generating the percentage of each class of use within the total administrative area of Rădăuţi. We mention that the total administrative surface of Rădăuţi has varied over time, the calculations being made according to the total surface of each year taken in the analysis. 

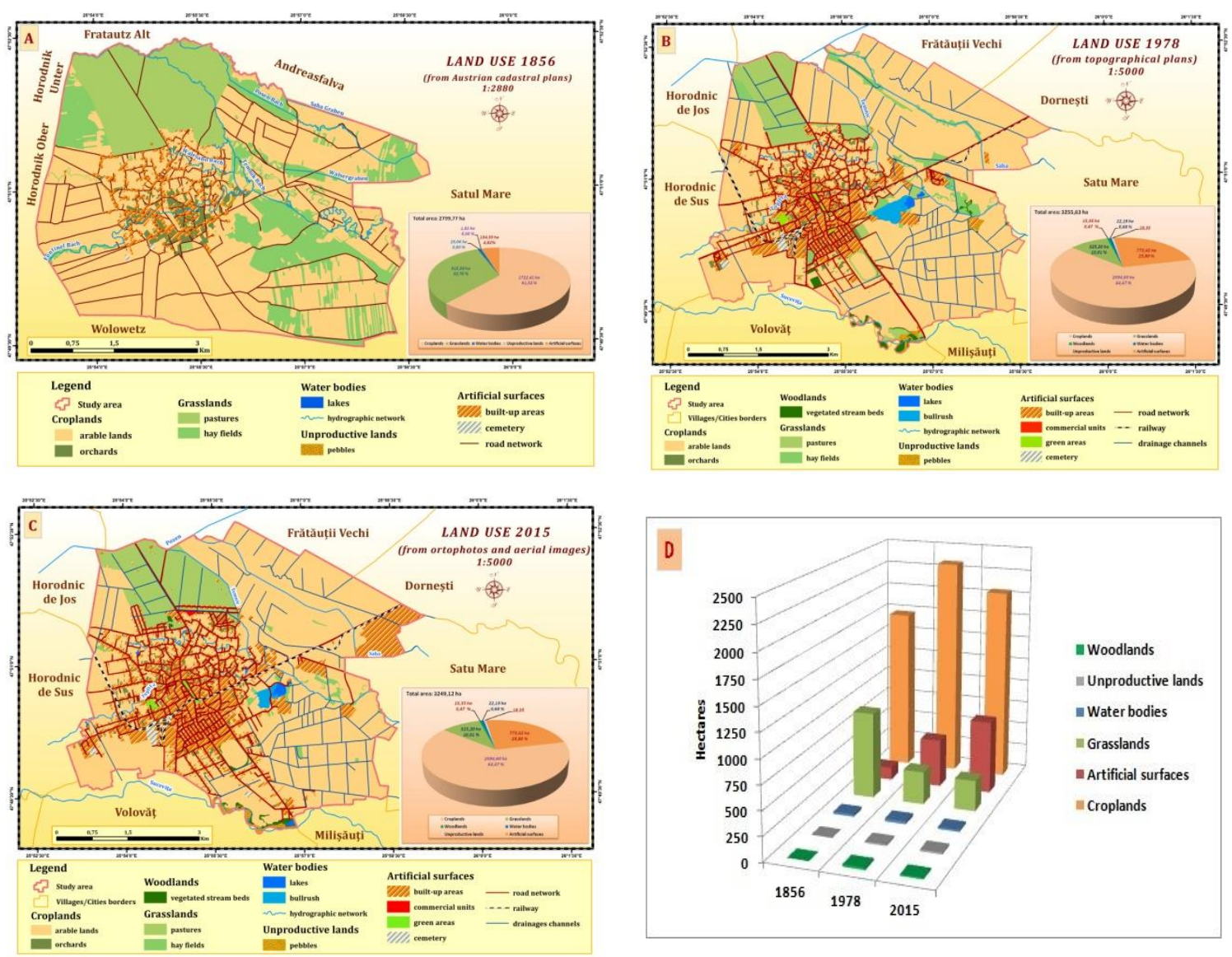

Figure 3. Spatial distribution of land use land cover in 1856 (A), 1978 (B), 2015 (C) and the evolution of the area of the main land use land cover classes (D).

Land cover change in the period 1856-1978

During the period from 1856 to 1978, we observed increases at majority of land use land cover classes due to fact that total area of studied area has increased from 2799,77ha in 1856 to 3255,63 ha in 1978 . The land cover change, which includes an assessment of the net gain or net loss, are reported in the Figure 4. The results show that there was an increase in areas covered by croplands, artificial surfaces, water bodies and unproductive lands. The use of five classes for the year 1856 can be explained by the fact that in this year the studied area has a different administrative border and did not include the area form the south, where is the woodlands influenced in their existence and development by the Sucevița river.

The most significant increases registered for croplands, from 1722,41ha $(61,52 \%)$ in 1856 to 2329,50 ha $(71,55 \%)$ in 1978 , thus, a total increase of 606,89 ha $(35,23 \%$ absolute rate of change) and for artificial surfaces, from 134,98 ha $(4,82 \%)$ to 508,30 ha $(15,61 \%)$, which showed a total increasing of $373,37 \mathrm{ha}(276,71 \%$ absolute rate of change). The other hand, the only land cover class which registered a significant decrease in this period were grasslands class, which decrease from $915,56 \mathrm{ha}(32,7 \%)$ to $348,15 \mathrm{ha}(10,69 \%)$, thus, a total decrease of 567,41 ha $(61,97 \%$ absolute rate of change). 


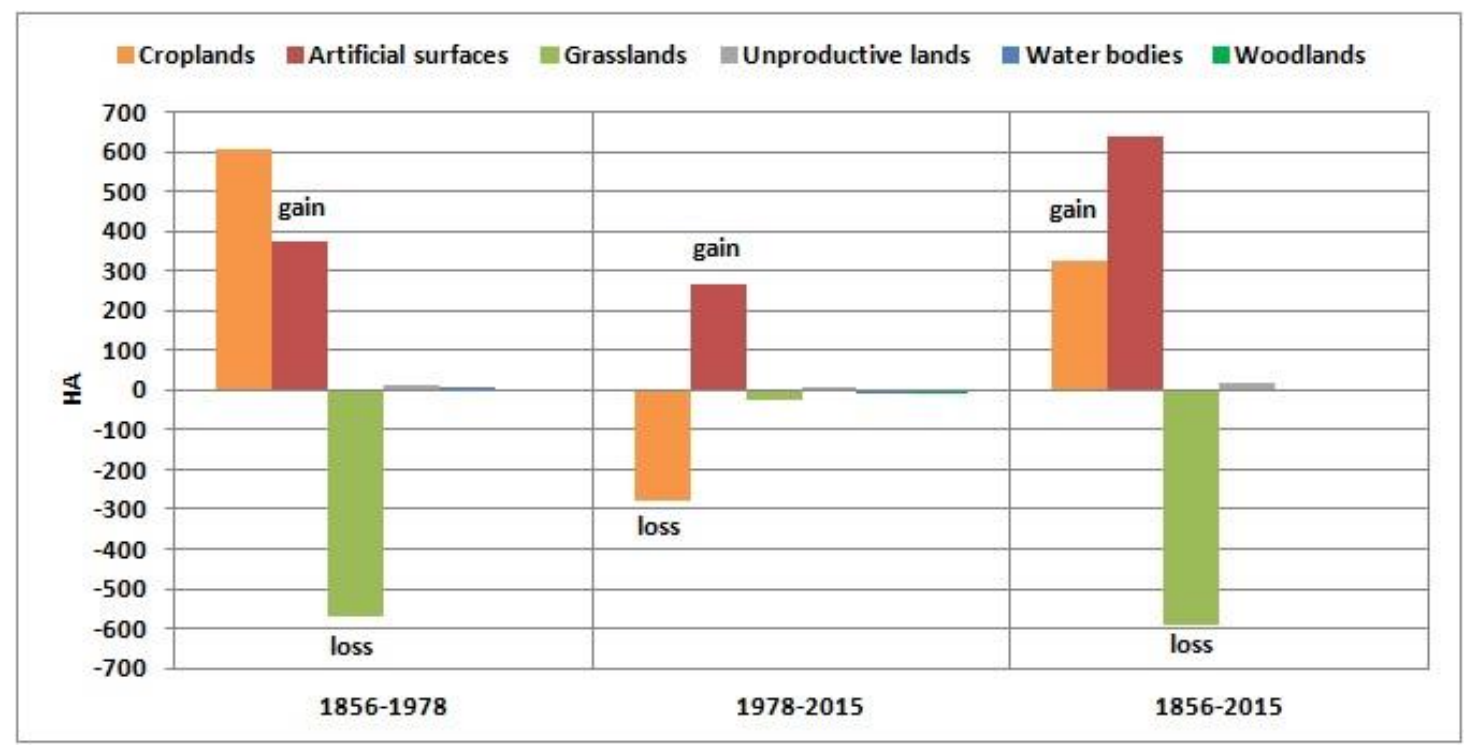

Figure 4. Absolute changes in land use land cover classes, expressed in hectares

Land cover change in the period 1978-2015

The period from 1978 to 2015 registered decreases at majority of land use land cover classes, with the exception of artificial surfaces which increases continuously from 508,30 ha $(15,61 \%)$ in 1978 to 773,42 ha $(23,80 \%)$ in 2015 , thus, an absolute rate of change of $265,12 \mathrm{ha}(52,16 \%)$. Secondly, other land use land cover class which registered an increase in the term of area were unproductive areas, which increases from 15,95ha $(0,49 \%)$ in 1978 to 18,35 ha $(0,56 \%)$ in 2015 , thus, an absolute rate of change of 2,40 ha $(15,05 \%)$. In this period, are observed different conversions of land use land cover classes, notably the conversion of semi-natural areas in artificial surfaces, due to continuously expansion of built-up area and adjacent infrastructure.

Land cover change over the entire period of study

Considering the entire period from 1856 to 2015, we observed significant changes of urban landscape, especially in the case of semi-natural surfaces which decreases continuously to the detriment of artificial surfaces (built-up spaces, infrastructure and urban utilities). Despite the fact that, the total area of studied area has increased, the area occupied by grasslands has decreased from 915,56ha $(32,70 \%)$ in 1856 to $325,20 \mathrm{ha}$ $(10,01 \%)$, thus, a total net loss of 590,36ha $(64,48 \%)$. Artificial surfaces, croplands and unproductive lands experienced important net gain surfaces, due to conversions at the level of studied area in the context of urban sprawl. In this case, the artificial surfaces class has experienced a total net gain of 638,49 ha $(473,20 \%)$, from 134,98 ha $(4,82 \%)$ to 773,42 ha $(23,80 \%)$, due to expansion of residential areas, commercial and industrial units, in the context of ever-increasing demands for space.

\section{DISCUSSIONS}

Eastern Europe has experienced several dramatic changes in government and political systems in the past two centuries, driving pronounced land-use changes [52], [53], [54]. These changes can be grouped into several time periods [54], [55].

During the 1800s (the Austro-Hungarian Empire), there was a general trend away from feudalism to land ownership by peasants, along with the introduction of new crops and technologies such as the steel plow [55]. 
After World War I, agricultural practices further intensified with new machinery, the introduction of natural mineral fertilizer, and a shift from subsistence agriculture to market-oriented production [55].

After World War II, under Soviet influence, most countries in Eastern Europe experienced dramatic agricultural intensification through collectivization of agricultural land with an increase in farm and field sizes, further mechanization, and increased use of agrochemicals [55]. Most recently, as Eastern European countries have acceded to the European Union, there has been a mix of agricultural abandonment in marginal areas, intensification, and some re-cultivation of formerly abandoned land [56].

For each analyzed period, a map for a year that reflects the period it belongs to was taken into account as follows: 1856 for the Austrian occupation period, 1978 for the socialist period, and 2015 for the capitalist period. Depending on the level of detail of the historical maps $(1856,1978)$ or aerial images (2015), many land use patterns have been identified that have been grouped into a similar number of land use categories to perform the related diachronic analysis. In this way, for the map corresponding to 1856, the mosaic of land use was grouped into five major categories, while the maps for the other two years (1978 and 2015) contained six major categories of land use.

After the spatial distribution of the land use categories for the three analyzed, a number of functions of the GIS software were used to calculate the area of each category of use (in ha), respectively the percentage (\%) held by each of them by reporting to the total administrative area of Rădăuţi. Thus, both spatial and temporal variations of land use categories in the territory of Radauti in the period 1856-2015 could be highlighted both cartographically and statistically.

From the analysis of land use evolution, we can see how over the past 159 years, the predominant agricultural use of land has slightly decreased to the detriment of the expansion of artificial land (built-up areas, infrastructure). This fact, which is currently under development, is the consequence of a combination of social, economic, cultural, legislative factors: increasing the number of inhabitants, diversifying the anthropic activities, increasing the standard of living of the population, legislative measures adopted especially after 1990. The law 18 from 1991 is a good example of legislative measure which caused an excessive privatization and fragmentation of farmlands and woodlands. The changes are more visible and marked as a rhythm of manifestation with the establishment of the socialist regime, with the implementation of the measures of collectivization and mechanization of agriculture, industrialization and urbanization of Rădăuţi.

After the Second World War, the urban landscape was significantly modified due to a general improvement of economic conditions and due to specific reforms targeted in Romania, which resulted in radical changes in land management. In fact, land use was heavily influenced by the "Land reform". Practicing an extensive agriculture, the improvement of cultivation techniques and public financing involved a change in the landscape structure, because marginal areas were then introduced in culture. Consequently, with the increase of agricultural and industrial activities, roads and buildings have increased substantially.

Industrial activities started to become a source of income for the population, which has gradually increasing from 1800 (1300 inhabitants) to 1989, when the number of population has reached 30454 inhabitants (Figure 4). 


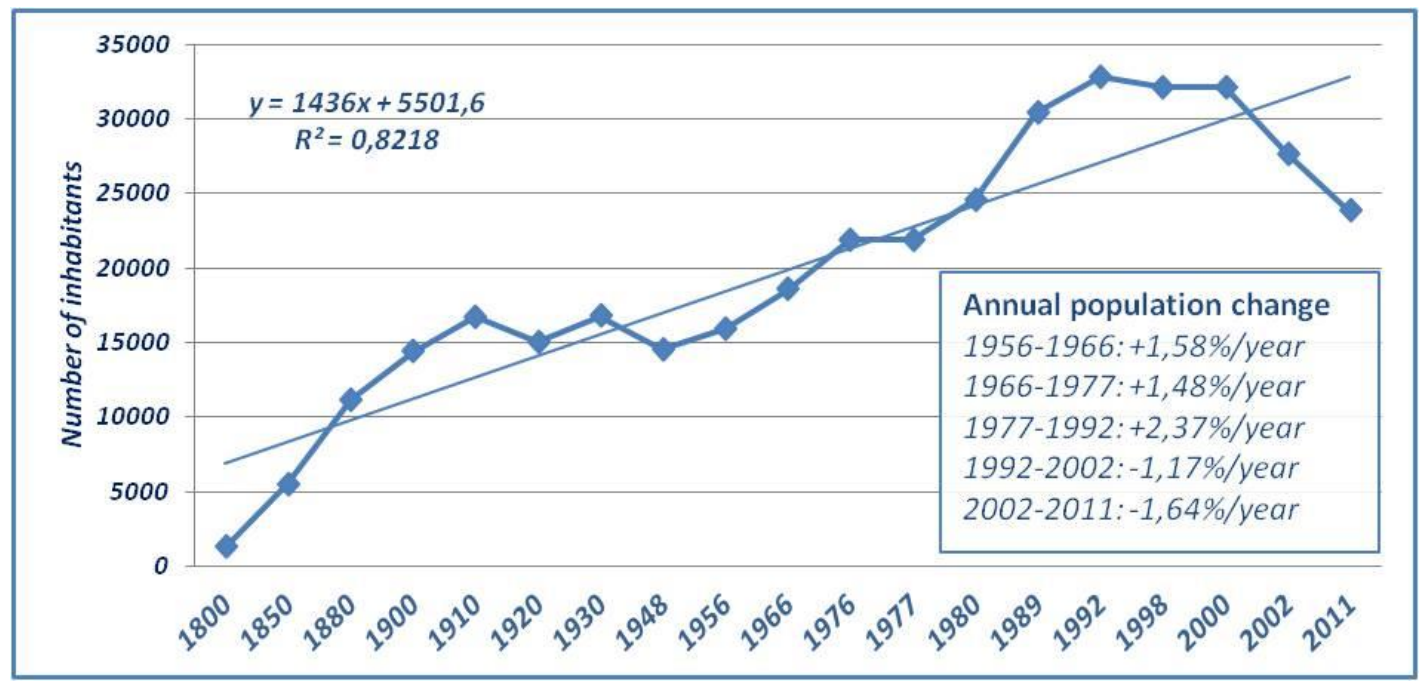

Figure 4. The evolution of the number of inhabitants in Rădăuți during 1800-2011

The increase of the population's needs, from an economic point of view, triggered landscape changes, and the studied area was transformed from a semi-natural zone to an agricultural area and to an urbanized area. As an argument to this information we can evoke the continuous growth of the artificial surfaces from 134,93ha $(4,82 \%)$ in 1856 to 508,30 ha $(15,61 \%)$ in 1978 and to 773,42 ha $(23,80 \%)$ in 2015 , on one hand, and the continuous decrease of the areas occupied by grasslands from 915,56ha $(32,70 \%)$ in (1856) to 348,15 ha $(10,69 \%)$ in 1978 and to 325,20 ha $(10,01 \%)$ in 2015 , on the other hand. First, the area occupied by grasslands were converted into croplands, fact which led to the increase of the areas occupied by cultivated lands, then it followed a conversion from croplands to artificial surfaces, as a result of the increase in the number of inhabitants who needed more space for housing development (Figure 5).

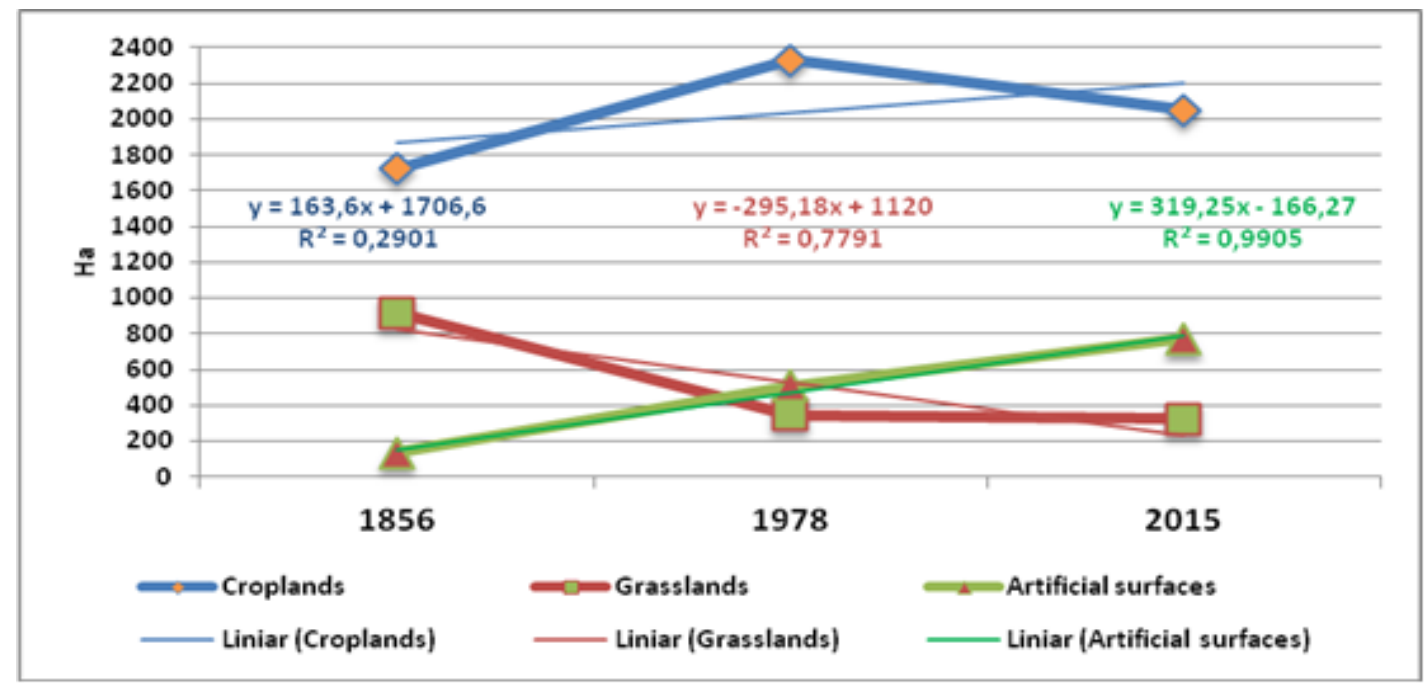

Figure 5. The evolution of dominant land use land cover classes in Rădăuți area

Another measure that has profoundly influenced the structure of the land fund at the level of Rădăuţi area is related to the legislative changes that took place after the fall of the socialist regime and which caused the privatization and excessive fragmentation of the land, the town planning policy of the city. 
The transition to market economy has led to significant changes at the level of industrial practices. In this way, at the beginning of the capitalist period, the number of unemployed has increased significantly following industry collapse and a great number of population going abroad to work, fact which is reflected by the continuously decrease of the population, especially after 1992 (see Figure 4).

Currently, the industry knows a revival process, especially the wood processing industry with the construction of Egger and Schweighofer factories (Figure 6). On the other hand, the permissive legislation in the field of residential expansion and the improvement of economic situation due to working abroad have determined the urban sprawl of Rădăuți municipality in the last decades.

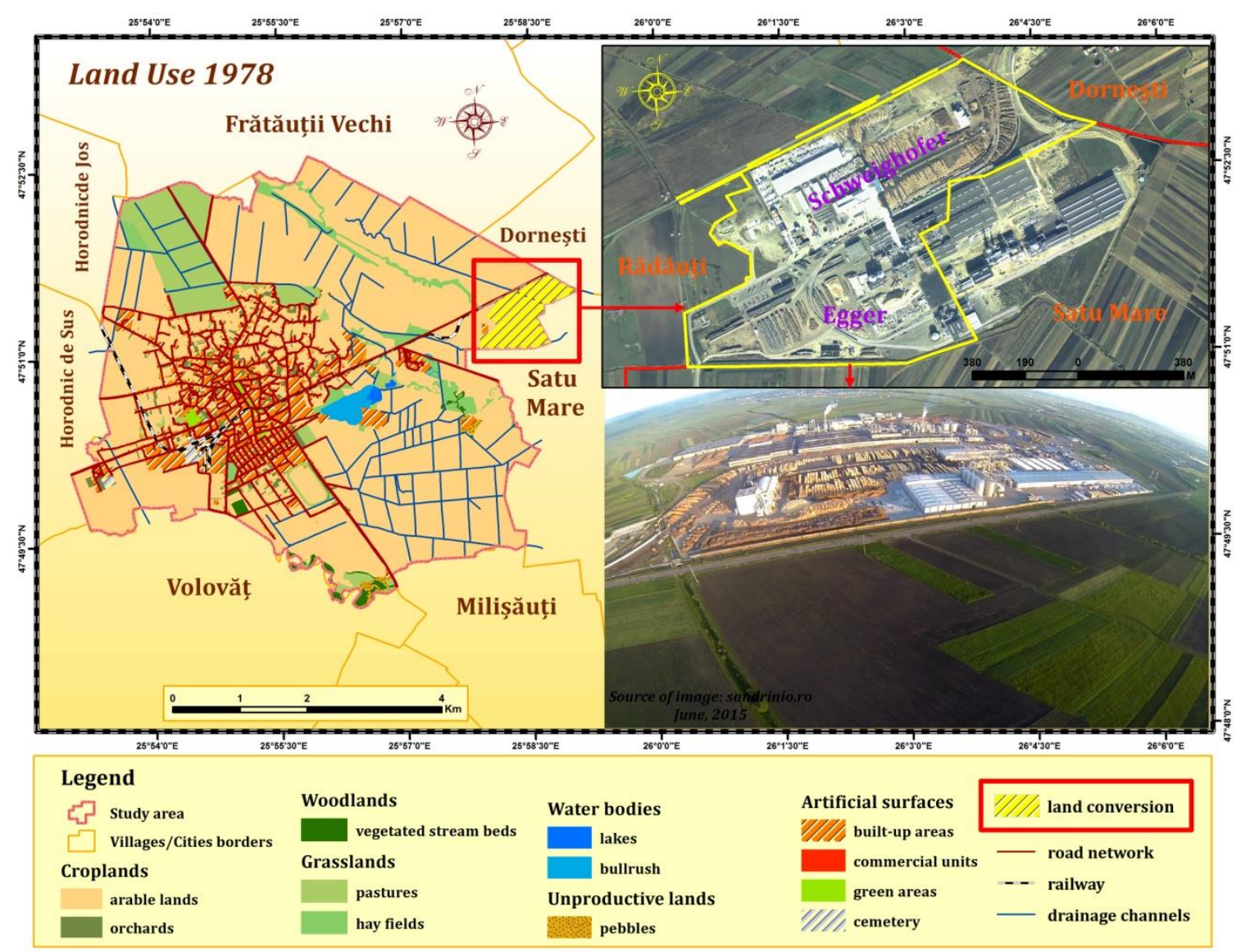

Figure 6. Example of land conversion from croplands (arable land) to built-up area (industrial unit) between 1978 and 2015

\section{CONCLUSIONS}

In the last two centuries, the area of Rădăuți has undergone significant land use changes. The analysis has allowed an assessment of the land use evolution on landscape changes and environmental changes over the 159 years that were investigated. One of the main achievements of this study was the rebuilding of land use history, with the use of historical maps, processed in a GIS software, that allows to study the "patterns of change over space and time" [57].

The structure of land fund reflects the high degree of rurality of the studied area, due to its evolution during time. Thus, the high weight of croplands and grasslands, on the one 
hand, and turning into a city in the second half of nineteenth century, on the other hand, were the main causes which reflect the high weight of semi-natural areas in this area. Although the urban spatial systems are complex in appearance and manifestation, as a result of their functional diversity, the (optimal or excessive) interaction between the natural environment and man often governs the deepest changes in the local geographic environment.

The diachronic analysis of land use dynamics proves useful in predicting urban expansion vectors including land use for the purpose of adopting and implementing best land management strategies and measures in the context of sustainable development of urban areas

The results show that the changes in the land use categories, manifested through conversions and changes, largely reflect the process of urbanization and territorial planning as a result of applying the political, economic and legislative measures specific to the three analyzed periods (government of Austrian-Hungarian Empire, socialist and capitalist periods).

GIS allows the implementation of historical maps, for quantitative and qualitative analysis, in order to understand the evolution of a landscape, with the aim to address adequate spatial planning, as well as proper land use management policies [58].

The diachronic analysis between past and present land use land cover represents a good approach for identifying landscape changes and quantifying the relationships among natural, socio-economic, cultural, political, law-making factors in the context of sustainable development.

The present approach may be equally applied to other areas from zones in which the datasets consisting of historical maps are available and which could be analyzed within a GIS software.

\section{REFERENCES}

[1] Žigrai, F. Integration meaning of land use study in geography and landscape ecology on example of model area Lúčky in Liptov (in Slovak), Geographical Studies, Univerzita Konštatntína Filozofa, Nitra, Slovakia, 133 pp, 1995.

[2] Branislav, O. Historical Maps and their Application in Landscape Ecological Research, Ekológia, Bratislava, Slovakia, vol. 28, no. 2, pp 143-151, 2009.

[3] Di Gregorio, A \& Jansen, L. J. M. Land Cover Classification System Classification concepts and user manual Software version (3), in: 8 EaNRS (ed). Food and Agriculture Organization of the United Nations, Rome, Italy, 40 pp, 2016.

[4] Cihlar, J. \& Jansen, L. J. M. From land cover to land use: A metodology for efficient land use mapping over large areas, Professional Geographer, vol. 53, no. 2, pp 275-289, 2001.

[5] Pelorosso, R. \& Leone, A. \& Boccia, L. Land cover and land use change in the Italian central Apennines: A comparison of assessment methods, Applied Geography, vol. 29, no. 1, pp 35-48, 2009.

[6] Lambin, E. F. \& Geist, H. J. Global LU/land-cover changes. What have we learned so far? IGBP Global Change Newsletter, no. 46, pp 27-30, 2001.

[7] Cousins, S.A.O. \& Eriksson, A. \& Franzén, D. Reconstructing past land use and vegetation patterns using palaeogeographical and archaeological data: A focus on grasslands in Nynäs by the Baltic Sea in south-eastern Sweden, Landscape and Urban Planning, vol. 61, no. 1, pp 1-18, 2002. 
[8] Petit, C.C. \& Lambin, E.F. Impact of data integration techniques on historical land-use/landcover change: comparing historical maps with remote sensing data in the Belgian Ardennes, Landscape Ecology, vol. 17, no. 2, pp 117-132, 2002.

[9] Vuorela, N. \& Petteri, A. \& Kalliola, R. Systematic assessment of maps as source information in landscape-change research, Landscape Research, vol. 27, no. 2, pp 141-166, 2002.

[10] Olsson, E.G.A. \& Austrheim, G. \& Grenne, S.N. Landscape change patterns in mountains, land use and environmental diversity, Mid-Norway 1960-1993, Landscape Ecology, vol. 15, no. 2, pp 155-170, 2000.

[11] Pärtel, M. \& Mändla, R. \& Zobel, M. Landscape history of a calcareous (alvar) grassland in Hanila, western Estonia, during the last three hundred years, Landscape Ecology, vol. 14, no. 2, pp 187-196, 1999.

[12] Verheyen, K. \& Bossuyt, B. \& Hermy, M. \& Tack, G. The land use history of a mixed hardwood forest in western Belgium and its relationship with chemical soil characteristics, Journal of Biogeography, 26, pp 1115-1128, 1999.

[13] Houghton, R.A. The worldwide extent of land-use change, BioScience, vol. 44, no. 5, pp 305-313, 1994.

[14] Lamarche, H. \& Romane, F. Analyse landschaftlicher Veränderungen aufgrund sozioökonomischer und ökologischer Kriterien am Beispiel einer südfranzösischen Gemeinde, Natur und Landschaft, vol. 57, pp 458-464, 1982.

[15] Antrop, M. Why landscape of the past are important for the future, Landscape and Urban Planning, vol. 70, no. 1-2, pp 21-34, 2005.

[16] Ewert, F. \& Rounsevell, M. D. A. \& Reginster, I. \& Metzger, M. \& Leemans, R. Future scenarios of European agricultural land use. I. Estimating changes in crop productivity, Agriculture, Ecosystems and Environment, vol. 107, no. 2-3, pp 101-116, 2005.

[17] Goudie, A. S. The Human Impact on the Natural Environment: Past, Present and Future (7th edition). Chichester, UK, Wiley-Blackwell, 424 pp, 2013.

[18] Marcucci D J. Landscape history as a planning tool, Landscape and Urban Planning, vol. 49, no. 1, pp 67-81, 2000.

[19] Foster, D. R. \& Swanson, F \& Aber, J. D. The importance of land-use legacies to ecology and conservation, BioScience, vol. 53, no. 1, pp 77-88, 2003.

[20] DeFries, R. S. \& Eshleman, K. N. Land-use change and hydrologic processes: A major focus for the future, Hydrological Processes, vol. 18, no. 11, pp 2183-2186, 2004.

[21] Bălteanu, D. The geographical significance of land use change (in romanian), Scientific Annals of Stefan cel Mare University of Suceava, Geography - Geology Section, Year V, 1996.

[22] Petrişor, A. I. Land cover and land use analysis of urban growth in Romania, Human Geographies, University of Bucharest Press, Bucharest, Romania, vol. 6, no. 1, pp 47-51, 2012.

[23] Goldewijk, K. K. \& Battjes, J. J. A hundred year (1890-1990) database for integrated environmental assessments (HYDE, version 1.1). National Institute of Public Health and the Environment (RIVM), Bilthoven, The Netherlands, 1997.

[24] Ramankutty, N. \& Foley, J. A. Estimating historical changes in global land cover: Croplands from 1700 to 1992, Global Biogeochemical Cycles, vol. 13, no. 4, pp 997-1027, 1999.

[25] Petit, C. \& Lambin, E. Long-term land-cover changes in the Belgian Ardennes (1775 - 1929): model-based reconstruction vs. historical maps. Global Change Biology, vol. 8, no. 7, pp 616630, 2002.

[26] Liu, J. \& Liu, M. \& Zhuang D. The recent spatial pattern of land use change in China, Scientia Sinica Terrae, vol. 32, no. 12, pp 1031-1040, 2002. 
[27] Turner, B. L. \& Lambin, E. F. \& Reenberg, A. The emergence of land change science for global environmental change and sustainability, Proceedings of the National Academy of Sciences, vol. 104, no. 52, pp. 20666-20671, 2007.

[28] Gragson, T. L. \& Bolstad, P. V. Land use legacies and the future of southern Appalachia, Society and Natural Resources, vol. 19, no. 2, pp 175-190, 2006.

[29] Haase, D. U. \& Walz, M.\& Neubert, \& Rosenberg, M. Changes to Central European Landscapes - Analysing Historical Maps to Approach Current Environmental Issues, Examples from Saxony, Central Germany, Land Use Policy, vol. 24, no. 1, pp 248-263, 2007.

[30] Brookfield, H. Environmental Damage: Distinguishing Human from Geophysical Causes, Global Environmental Change Part B: Environmental Hazards, vol. 1, no. 1, pp. 3-11, 1999.

[31] Pearson, B. C. Comparative Accuracy in Four Civil War Maps of the Shenandoah Valley: A GIS Analysis, Professional Geographer, vol. 57, no. 3, pp 376-94, 2005.

[32] Valent, P \& Rončák, P \& Maliariková, M \& Behan, Š. Utilization of Historical Maps in the Land use Change Impact Studies: A Case Study From Myjava River Basin, Slovak Journal of Civil Engineering, vol. 24, no. 4, pp 15 - 26, 2016.

[33] Kienast, F. Analysis of historic landscape patterns with a Geographical Information System: A methodological outline, Landscape Ecology, vol.8, no. 2, pp 103-118, 1993.

[34] Yang, Y. \& Zhang, S. \& Yang, J. \& Chang, L. \& Bu, K. \& Xing, X. A review of historical reconstruction methods of land use/land cover, Journal of Geographical Sciences. vol. 24, no. 4, pp 746-766, 2014.

[35] Fuchs, R. \& Verburg, P. H. \& Clevers, J. G. P. W. \& Herold, M. The potential of old maps and encyclopaedias for reconstructing historic European land cover/use change, Applied Geography, vol. 59, pp 43-55, 2015.

[36] Cogbill, C. V. \& Burk, J. \& Motzkin, G. The forests of presettlement New England, USA: Spatial and compositional patterns based on town proprietor surveys, Journal of Biogeography, vol. 29, no. 10/11, pp 1279-1304, 2002.

[37] Bolliger, J. \& Schulte, L. A. \& Burrows, S. N. Assessing ecological restoration potentials of Wisconsin (USA) using historical landscape reconstructions, Restoration Ecology, vol. 12, no. 1, pp 124-142, 2004.

[38] Tănasă I. Suceava Plateau Climate - Risk phenomena, implications for sustainable development (in Romanian), PhD Thesis, "Ştefan cel Mare" University of Suceava, Faculty of History and Geography, Suceava, Romania, 2011.

[39] Luchian D. Rădăuţi - Romanian hearth of socialist traditions and achievements (in Romanian), Ed. Litera, Romania, 332 pp, 1982.

[40] General Urbanistic Plan of Rădăuți Municipality, Vol. 1, 2008.

[41] National Institute of Statistics, 2011.

[42] Peil, T. Eesti kaartidel. (Estonia on maps). - Maran, T. \& Tüür, K. (eds.). Eesti looduskultuur. (Estonian natural culture). Tartu, Eesti Kultuuriloo ja Folkloristika Keskus, Eesti Kirjandusmuuseum (in Estonian), pp 327-362, 2005.

[43] Antrop, M. Background concepts for integrated landscape analysis, Agriculture, Ecosystems and Environment, vol. 77, no. 1-2, pp. 17-28, 2000.

[44] Cousins, S.A. Analysis of land-cover transitions based on 17th and 18th century cadastral maps and aerial photographs, Landscape Ecology, vol. 16, no. 1, pp 41-54, 2001.

[45] Domaas, S.T. \& Austad, I. \& Norderhaug, A. \& Timberlid, A. Historical cadastral maps as a tool for valuation of today's landscape elements, Mander, Ü. \& Printsmann, A., Palang, H. (eds.). Development of European landscapes, IALE European Conference Proceedings, 
Publicationes Instituti Geographici Universitatis Tartuensis. Tartu, Tartu Ülikooli Kirjastus, Estonia, 2001, vol. 1, pp 189-194.

[46] Tortora A. \& Statuto D. \& Picuno P. Rural landscape planning through spatial modelling and image processing of historical maps, Land Use Policy, vol. 42, pp 71-82, 2015.

[47] Chiang, Y. \& Leyk, S. \& Knoblock, C. A. A survey of digital map processing techniques, ACM Computing Surveys, vol. 47, no. 1, 44 pp, 2014.

[48] Baily, B. The extraction of digital vector data from historic land use maps of Great Britain using image processing techniques, e-Perimetron, vol. 2, no. 4, pp 209-223, 2007.

[49] Cajthaml, J. \& Krejčí, J. Využití starých map pro výzkum krajiny. Sborník z conference, GIS Ostrava, Czech Republic, 27-30.1.2008, pp 1-10.

[50] Rhemtulla, J. M. \& Mladenoff, D. J. \& Clayton M. K. Regional Land-Cover Conversion in the US Upper Midwest: Magnitude of Change and Limited Recovery (1850-1935-1993), Landscape Ecology, vol. 22, no. S1, pp 57-75, 2007.

[51] Pindozzi, Stefania \& Cervelli, Elena \& Capolupo, Alessandra \& Collins, O. \& Lorenzo, B. Using historical maps to analyze two hundred years of land cover changes: case study of Sorrento peninsula (south Italy), Cartography and Geographic Information Science, vol. 43, no. 3, pp 250265, 2015.

[52] Lerman Z, Csaki C \& Feder G. Evolving farm structures and land use patterns in former socialist countries Quarterly Journal of International Agriculture, vol. 43, no. 4, pp 309-336, 2004.

[53] Hostert P \& Kuemmerle T \& Prishchepov A \& Sieber Anika \& Lambin E. F. \& Radeloff V. C. Rapid land use change after socio-economic disturbances: the collapse of the Soviet Union versus Chernobyl, Environmental Research Letters, vol. 6, no. 4, 2011.

[54] Munteanu C \& Kuemmerle T \& Boltiziar M \& Butsic V \& Gimmi U \& Halada L \& Kaim D \& Király G \& Konkoly-Gyuró É \& Kozak J \& Lieskovský J \& Mojses M \& Müller D \& Ostafin K \& Ostapowicz K \& Shandra O \& Štych P \& Walker S \& Radeloff V. C. Forest and agricultural land change in the Carpathian region - a meta-analysis of long-term patterns and drivers of change, Land Use Policy, vol. 38, pp 685-697, 2014.

[55] Jepsen, M.R. \& Kuemmerle, T. \& Müller, D. \& Erb, K. \& Verburg, P.H. \& Haberl, H. \& Vesterager, J.P. \& Andric, M. \& Antrop, M. \& Austrheim, G. \& Bjorn, I. \& Bondeau, A. \& Burgi, M. \& Bryson, J. \& Caspar, G. \& Cassar, L,.F \& Conrad, E \& Chromy, P \& Daugirdas, V \& Van Eetvelde, V \& Elena-Rossello, R \& Gimmi, U \& Izakovicova, Z \& Jancak, V \& Jansson, U \& Kladnik, D \& Kozak, J \& Konkoly-Gyuro, E \& Krausmann, F \& Mander, U \& McDonagh, J \& Parn, J \& Niedertscheider, M \& Nikodemus, O \& Ostapowicz, K \& Perez-Soba, M \& PintoCorreia, T \& Ribokas, G \& Rounsevell, M \& Schistou, D \& Schmit, C \& Terkenli, T. S \& Tretvik, A. M \& Trzepacz, P \& Vadineanu, A \& Walz, A \& Zhllima, E \& Reenberg, A. Transitions in European land-management regimes between 1800 and 2010, Land Use Policy, vol. 49, pp 5364, 2015.

[56] Estel, S \& Kuemmerle, T \& Alcantara, C \& Levers, C \& Prishchepov, A \& Hostert, P. Mapping farmland abandonment and recultivation across Europe using MODIS NDVI time series, Remote Sensing of Environment, vol. 163, pp 312-325, 2015.

[57] Knowles, A. K. Introducing Historical GIS. In Past Time, Past Place: GIS for History, edited by A. K. Knowles, XI-XX. Redlands, CA: ESRI Press, 2002.

[58] Statuto, D \& Giuseppe, C \& Picuno, P. Using historical maps within a GIS to Analyze Two Centuries of Rural Landscape Changes in Southern Italy, Land, vol. 6, no. 3, 65, 2017.

*** The annual statistical report of Suceava county from 2011.

*** http://population.city/romania/radauti/ (accessed at 26 January 2018).

*** http://geoportal.ancpi.ro/ (accessed at 14 January 2018). 
*** The Dorf Bukovina Austrian Maps from 1856, scale 1:2880.

*** The topographical plans from 1978, scale 1:5000.

*** Ortophotos from 2010.

*** Aerial images from 2015 downloaded with TerraIncognita 2.41 . 